\title{
5 Physicians, Midwives, and Female Patients
}

When drawing on Arabic medical texts in an attempt to shed light on how women experienced infertility, we must ask the question: did the ideas articulated in these texts ever have a practical impact on the way medieval infertile women were treated or how they perceived their infertility? After all, what we have are theories and practices described in books, in a world in which the vast majority of women were not taught to read. While some biographical dictionaries include accounts of individual women who did master a particular body of oral or written texts (such as hadith literature, or poetry), we have no such account in the realm of medicine. Therefore, Arabo-Galenic gynecology could have practical implications only if male participants in this literate medical culture shared this culture with female medical practitioners or communicated their ideas directly to female patients. One might well assume, as Manfred Ullmann does, that neither of these things could occur, on the grounds that women would have lacked interest in male opinions about female bodies, or on the grounds that modesty concerns made such interactions taboo. The extant sources, however, do not buttress such assumptions, and instead point at a very different state of affairs.

As a caveat to her own scholarship on ancient gynecological theories, Monica Green writes:

[T] he transmission of ancient traditions must be understood as a primarily intellectual and literary phenomenon. In all of the cultures discussed . . . literacy levels were so low that a textual medium of knowledge would ipso facto have been inaccessible to the vast majority of people. Hence the reader should not assume (nor have I meant to imply) that the medical practices described here were necessarily those most regularly performed when a woman complained of any illness. Nor, additionally, can we always be sure that the theories expounded in medical literature reflect the attitudes of the contemporary society at large. ${ }^{488}$

The same caveats may be applied to the communities under discussion in this study. When it comes to medieval Middle Eastern societies, we currently have no way of objectively assessing the relative frequency of women receiving gynecological care that was influenced by the Arabo-Galenic literary tradition, as opposed to care guided by familial or local medical lore, or care predicated on religious intervention or the manipulation of supernatural forces. (The intellectual ramifications of these forms of healing are explored from the perspective of certain Islamic jurists in the next chapter.) What we do have, instead, are many tan-

488 Green, "The Transmission of Ancient Theories of Female Physiology,” 7.

Ә OpenAccess. (C) 2020 Sara Verskin, published by De Gruyter. (cc))BY-NC-ND This work is licensed under the Creative Commons Attribution-NonCommercial-NoDerivatives 4.0 License. 
talizing remarks that shed light on the feasibility of women receiving gynecological care in the Arabo-Galenic medical tradition.

In the regions and time-period from which there is extant literature (which may well not be representative of the majority of communities), that literature depicts environments in which male physicians interact with female patients, though women appear in only a relatively small percentage of the individual cases mentioned. ${ }^{489}$ Literary works, books of medical ethics, biographical dictionaries detailing the exploits of physicians, guides to inspectors policing the marketplace, and works of religious preaching and public morality describe a variety of professional interactions between male physicians and female patients. They refer to medical consultations and to women submitting their urine to male physicians for uroscopy, just as their male counterparts do. ${ }^{490}$ Male phlebotomists are depicted as bleeding women. Male physicians examine women in the course of making house calls, take their pulse, ${ }^{491}$ and at times engage in

489 E. g., Abū Bakr Muhammad ibn Zakarīyā al-Rāzī, Kitāb al-tajārib: ma'a dirāsa fī manhaj albahth al-ílmī 'inda al-Rāzī (Alexandria: Dār al-Wafā' li-Dunyā al-Ṭibā'a wa'l-Nashr, 2006), 247252. The other two known clinical experience casebooks are al-Majālis fī al-țibb by Abū Ja'far Aḥmad b. 'Īsā al-Hāshimī (fl. $5^{\text {th }} / 11^{\text {th }}$-century) and Kitāb al-Mujarrabāt by Ibn Zuhr, both from Spain.

490 In Ibn al-Ruhāwì's Adab al-țabīb there are several anecdotes about women submitting their urine for uroscopy, particularly in order to determine pregnancy and fetal sex. See M. Levey, "Medical Ethics of Medieval Islam with Special Reference to Al-Ruhāwì's 'Practical Ethics of the Physician," 74-75.

491 Consider this anecdote from al-Ghazālī's Ihyyā 'ulūm al-dīn: "Someone complained to a physician about his wife being infertile and not bearing any children. The physician felt her pulse and said: 'No need to worry about infertility treatment, for you are going to die in forty days, as is indicated by your pulse.' The woman was overcome with fear and lost all appetite for life; she took out her money, divided it and bequeathed it. She remained without eating and drinking, but the [allotted] time passed without her dying. The husband went to the physician and said: 'She did not die.' He replied: 'I know that. Have sex with her now, and she will give birth.' The husband retorted: 'How so?' The physician explained: 'I saw that she was overweight, and that fat had collected at the orifice of the womb. Moreover, I knew that she would only lose weight if she were afraid of dying, so I put this fear into her. Thus she lost weight, and the obstacle against conception has disappeared."' Translation (modified) from Peter Pormann's text study handout, "Female Patients, Patrons and Practitioners in $10^{\text {th }}$ and $11^{\text {th }}$-Century Baghdad: An Unheard Voice?” Institute of Islamic Studies at McGill University, Montreal, May 4, 2007. In another text from the same period called Da 'wat al-ațibbä', the Christian physician Ibn Butlān complains that people have absurd and scientifically impossible expectations of physicians, and he lists as an example of such expections, the notion that a physician should be able to distinguish a barren from a fruitful woman by feeling her pulse. See. F. Rosenthal, "The Defense of Medicine In The Medieval Muslim World," Bulletin of the History of Medicine 43 (1969):529. 
more intimate forms of touch. Medical texts also recommend surgeries to be conducted on women, including on their genitals and in obstetrical situations. As for the role occupied by female medical providers in the ecosystem of learned gynecology, the situation is remarkably ambiguous, not only when comparing across communities, but even when considering the writings of individual authors.

\section{Non-gynecological interactions between male medical professionals and female patients}

Descriptions of market activity from $6^{\text {th }}-7^{\text {th }} / 12^{\text {th }}-13^{\text {th }}$-century Islamic Spain, Egypt, and Syria portray physicians, pharmacists, surgeons, bonesetters and assorted other medical personnel having storefronts in the market or in similar settings in which women were present. ${ }^{492}$ At least some of the medical care provided in these settings clearly reflects the Arabo-Galenic medical tradition. These descriptions come from books of hisba, guides for market inspectors whose job it was to prevent fraud and physical and moral pollution in the market and other public places. Concerns about the potential for sexual exploitation of women, and scandalous behavior on the part of women, feature prominently in this genre of literature. However, medical practitioners are not particularly scrutinized in this regard.

Hisba manuals indicate that, at least in some communities, it was acceptable for male medical practitioners to touch female clients. For example, according to a $6^{\text {th }} / 13^{\text {th }}$-century Syrian hisba manual by al-Shayzarī, male phlebotomists perform cupping on women's thighs to bring down the menses, a practice which is also recommended in the theoretical medical literature. ${ }^{493}$ Similarly, a manual by Ibn al-Ukhuwwa, written in $7^{\text {th }} / 14^{\text {th }}$ Mamluk Egypt, describes male phlebotomists bleeding women, with no mention of modesty-based concerns in doing so. This is the case despite the fact that the author mentions regulations based on

492 See S. Hamarneh, "Origin and Functions of the Hisbah System in Islam and Its Impact on the Health Professions," Sudhoffs Archiv für Geschichte der Medizin und der Naturwissenschaften 48 (1964), 157-63 and M. Meyerhof, "La surveillance des professions médicales et paramédicales chez les Arabes,” Bulletin de l'Institut d'Égypte 26 (1944), 119-34. Chipman, The World of Pharmacy and Pharmacists in Mamlūk Cairo, 70. See Abū'l-Munā al-Mūhīn al-'Ațtāar, Minhāj al-dukkān wa-dustūr al-ayān (Beirut: Dār al-Manāhil, 1992), 16; Ibn al-Ukhūwwa, The Ma'ālim al-qurba fī aḥkām al-ḥisba, 54-59; 'Ibn 'Abdūn al-Tujibī and E. Lévi-Provençal, Séville Musulmane Au Dé but Du XIIe Siècle: Le Traité D’ibn Abdun Sur La Vie Urbaine Et Les Corps De Métiers (Paris: G. P. Maisonneuve, 1947), §139-40.

493 al-Shayzarī, Kitāb Nihāyat al-rutba fì țalab al-ḥisba, 96. See Ibn Sīnā, Qānūn fĩ al-țibb 2:589 = Kitāb 3: fann 21: maqāla 3: faṣl fì al-mu'ālajāt. 
modesty concerns in other, non-medical situations. Moreover, when addressing phlebotomists, Ibn al-Ukhuwwa mentions other caveats, but none of these reflect concerns about modesty or sexual taboos.

No slave must be bled without the owner's permission, nor a minor without that of his guardian, nor a pregnant woman, nor one menstruating. Bleeding must not be performed except in a public place, nor with any but a sharp instrument, nor when he [the operator] is in a state of mental agitation. The muhtasib must exact a promise and a bond from them that in ten specified cases they will not bleed except after consultation with physicians . . ${ }^{494}$

Here we see menstruation and pregnancy treated as counterindications for bleeding, not as taboo subjects thwarting male medical inquiry and involvement. Indeed, Ibn al-Ukhuwwa later specifically mentions the usefulness of bleeding the saphenous vein to provoke menstruation. (He also mentions counter-indications with respect to male reproduction. He prohibits phlebotomists from cutting or bleeding the veins behind the ears, for fear that it will induce male sterility. Al-Shayzarī includes a slightly longer discussion of this notion, which also appears in the Hippocratic treatise Airs, Waters, Places. ${ }^{495}$ )

Ibn al-Ukhuwwa also instructs the inspector to ensure that the phlebotomist is prepared to conduct circumcisions, on both males and females.

The phlebotomist should carry with him instruments for circumcision (consisting of a razor and scissors), for it is a duty incumbent upon both men and women. To this the generality of men of learning agree. Abū Ḥanīfa called it a recommended practice, but not a compulsory duty. For the male, it consists in abscission of the prepuce hiding the glans penis, for the female in cutting the skin over the vagina and above the urethra. It is a practice compulsory upon men and women, who must carry it out on themselves and on their children. If it is neglected, the imam must enforce its being carried out. ${ }^{496}$

That phlebotomists were tasked with circumcision can be attributed to their having the requisite sharp tools in their possession. A $13^{\text {th }}$-century Egyptian shadow play titled, al-Șāni'a, "The Female Practitioner," features a woman, probably a gypsy, as the titular character, and she is depicted bearing a satchel, lances, cupping glasses, and needles with which she fulfills her roles as phlebotomist, tattooer, circumciser, and fortune-teller. ${ }^{497}$ While female phlebotomists are not

494 Ibn al-Ukhūwwa, The Ma'ālim al-qurba fī aḥkām al-ḥisba, 54. Levy’s translation.

495 Al-Shayzarī, Kitāb Nihāyat al-rutba fī țalab al-ḥisba, 92

496 Ibn al-Ukhuwwa, The Ma'ālim al-qurba fĩ aḥkām al-ḥisba, 56. Levy’s translation.

497 P. E. Kahle, “A Gypsy Woman in Egypt in the Thirteenth Century A.D.” Journal of the Gypsy Lore Society, third series, 29 (1950):11-15. 
mentioned in Ibn al-Ukhuwwa's text, they were often involved in female circumcisions in Egypt. ${ }^{498}$ Furthermore, in legal literature there is a history jurists encouraging physicians to teach women to perform circumcisions and other medical procedures in order to avoid subjecting women to a male gaze. ${ }^{499}$ However, in Ibn al-Ukhuwwa's manual, the description of how to conduct female circumcisions uses masculine grammatical forms for the practitioner. ${ }^{500}$

In addition to hisba manuals, medical texts too also give the impression that male practitioners perform circumcisions and genital excisions on women. The $4^{\text {th }} / 10^{\text {th }}$-century physicians Ibn Sīnā and al-Zahrāwī, both writing in contexts where female circumcision was not a common practice (in Iraq and Spain respectively) describe in their medical texts how a male physician should go about performing clitorectomies when the clitoris is abnormally large. Ibn Sīnā, for his part, expresses some skepticism regarding whether such a condition actually exists and, if it does, whether it cannot be better managed without surgery. ${ }^{501} \mathrm{Al}$-Zahrāwī does not mention such doubts but, following quite closely Paul of Aegina's description of the procedure in his book on surgery, writes "You [masculine] must grasp the clitoris with your hand or with a hook and cut it off. Do not cut too deeply . . . and as for a fleshy growth growing in the cervix and filling it . . you should cut this too, just as you cut off the clitoris." 502 Al-Zahrāwī is quite clear that it is a male physician performing the operation, and that the surgery entails touching the genitals. One could make the argument that al-Zahrāwī does not consider the clitoris to be female genitalia, and that the medical scenario is thus not considered gynecological or sexually fraught. (He refers to the operation as cutting a clitoris which is so large as to look "deformed" and "erect like a man's" penis). His chapter describing the procedure (chapter 71) precedes the chapters on gynecological surgery but immediately follows the chapter on treating hermaphrodites (chapter 70) and on the mechanics of male castration (chapter 69), which in turn is preceded by chapters on male genitalia. This sort of organization may imply a view that the uncircumcised girl constitutes a stage on a masculine-to-feminine continuum, which moves from males, to castrated men, to hermaphrodites, to uncircumcised girls, to

498 Berkey, "Circumcision Circumscribed: Female Excision and Cultural Accommodation in the Medieval Near East,” 20.

499 Ibn ‘Ābidīn, Ḥāshiyat Radd al-muhtār, 9:533.

500 Ibn al-Ukhuwwa, The Ma'ālim al-qurba fĩ aḥkām al-ḥisba, 164 in the Arabic.

501 Ibn Sīnā, Qānūn fì al-țibb, 2:603 = kitāb III: fann 22: maqāla 1, faṣl fì al-laḥm al-zā’id wa-ṭūl il-bazr.

502 al-Zahrāwī, Albucasis on Surgery and Instruments, 457. Cf. Paul of Aegina and Francis Adams, The Seven Books of Paulus Fgineta (London: Sydenham Society, 1844), 2:381. 
full-fledged women. The chapter in question is taken verbatim from Paul of Aegina's book on surgery, which maintains the same chapter order. ${ }^{503}$

It could perhaps be argued that phlebotomists and surgeons are distinct from physicians, and thus are not elite enough to be considered a threat to sexual respectability nor sufficiently theoretically trained as to be able to communicate Arabo-Galenic medical theory and practice to their patients. However, we also hear of physicians treating women and conversing with them about both medical and non-medical topics. This appears to be the case both in the households of the nobility, where modesty constraints were usually greatest, as well as in less elite households in a variety of places and periods. Numerous tales recounted by Ibn Abī Ușaybī‘a in his biographical dictionary of physicians,

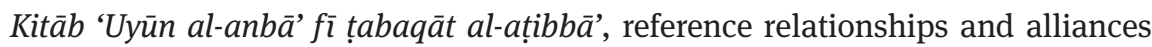
between male physicians and female patients in the royal household. Some of these relationships are described as occurring at a distance and through intermediaries, such as the one between Khayzurān, the mother of the famed 'Abbasid caliphs al-Hādī and Hārūn al-Rashīd, and the physician Abū Quraysh. But there are also numerous mentions of physicians visiting the women's quarters. For example, the Samaritan physician and vizier to the Ayyubids Muhadhdhab al-Din Yūsuf ibn Abī Sa'īd (d. 624/1227), served as the personal physician to both the male and female members of the royal household. In one story about him a friend of his, a judge, fell out of favor at court and asked Muhadhdhab al-Dīn to advocate for him. In an effort to help, the physician turned to his allies in the harem:

Seriat al-Malik al-'Adil, the mother of al-Malik al-Sālih ibn al-Malik, was unwell at that time. She was of Turkish origin, an intelligent, pious and good woman, very kind and generous. When the Doctor Muhadhdhab al-Dīn came to see her in the harem, he acquainted her with the case of the judge, his troubles and the unjust treatment meted out to him ... The chief eunuch supported Muhadhdhab’s request. But Seriat said: "How can I do anything for the judge, or even mention him to the Sultan? I cannot, because he will ask: 'What makes you speak about the judge, and how is it that you know him?' If he were, say, a doctor who visits us from time to time, or a merchant who sells us cloth, it would be possible for me to talk and intervene; but as it is, I can do nothing." ${ }^{504}$

503 Paul of Aegina and Francis Adams, The Seven Books of Paulus Fgineta (London: Sydenham Society, 1844), 2:381. Cf. Ibn Sīnā, Qānūn fĩ al-țibb, 2:603 = kitāb III: fann 22: maqāla 1, fașl fī allaḥm al-zāid wa-țūl il-baẓr in which Ibn Sīnā describes the same surgery, but says there is disagreement as to whether this condition even exists and whether or not it can be managed without surgery.

504 Translation from L. Kopf, Lives of the Physicians http://www.tertullian.org/fathers/ibn_abi_ usaibia_03.htm, p. 905. Ibn Abī Ușaybī‘a, 'Uyūn al-anbā̄' fì țabaqāt al-ațibbō̄' (Beirut: Dār Maktaba al-Ḥayāt, 1965), 730. 
The woman and the physician then concoct a scheme which ultimately succeeds. From this passage, it is evident that not only does the physician visit the noblewomen, but that he occupies one of the few professions that are perceived as having legitimate business in the harem. The noblewoman says it would seem suspicious for her to be aware of the political fortunes of a judge and to intervene on his behalf, but it would not be inappropriate for her to be seen to do so on behalf of a physician or cloth merchant. The story indicates that in this noblewoman's particular community there are opportunities for educated physicians to converse with women without violating social norms.

Other anecdotes recounted by Ibn Abī Ușaybī'a suggest that physicians who personally attended the women of noble households may have been in highly sensitive positions that occasioned some awkwardness, but such obstacles were not insurmountable. The story is told of Sa'īd ibn Tufīl (d. 279/892), an Egyptian physician to the famed founder of the Tulunid dynasty Ahmad ibn Ṭūlūn, and his accidental protegee in the medical arts, Hāshim.

\begin{abstract}
When Sa'īd ibn Tufîl first associated with Ahmad, he had a hireling of ugly appearance, called Hāshim, who, together with his father, worked with flax. He tended Sa'īd's mule and kept watch on it when Sa'īd entered the house of Ahmad ibn Tūlūn. Sa'īd occasionally had him pound drugs at his house when he took him home with him, and blow upon the fire over the concoctions. Sa'îd ibn Tufil had a son of handsome appearance, endowed with intelligence and a sound knowledge of medicine. At the beginning of their acquaintanceship, Aḥmad ibn Tūlūn instructed Sa'īd to find a physician for his womenfolk, who would reside at the court during Sa'īd's absence. Said Sa'īd: 'I have a son whom I have taught and made proficient.' Said Ahmad: 'Present him to me.' When he was introduced, Ahmad, seeing a handsome youth, possessed of all good qualities, commented to Sa'īd: 'He is not suitable to serve the women; for them I need a person of great knowledge, but ugly appearance.' Sa'īd was reluctant to have a stranger attend the women, for fear that he might disagree and clash with him. He therefore took Hāshim, provided him with a dira'a [a loose outer garment] and slippers and appointed him to the women . . .

'Umar asked Sa‘īd: 'In what position did you install Hāshim?' Sa‘īd replied: 'In the service of the women, for the Emir wanted a person of unprepossessing appearance.' Said 'Umar: 'An ugly person with a sound education, fitting the post, could surely have been found among the sons of physicians. You have disgraced the profession ...'
\end{abstract}

From this account it would seem that, in the Tulunid court, women were seen by trained male physicians, but it was a position appropriate to a junior person, though still a person old enough to be potentially sexually appealing. The ideal physician under such a circumstance was someone well-educated but not physically attractive. The story continues with Hāshim's great success among the noblewomen, who then personally make the introductions between their trusted physician and the sultan himself. 
Hāshim acquired such high prestige among the women that they preferred him even to Sa'īd, for he prepared medicines which had a beneficial effect on them as regards fatness, pregnancy, the complexion and the growth of hair. When Aḥmad ibn Tūlūn's ailment became very severe and the physicians assembled in his presence every morning, Mi'at Alì, the mother of Abū'l-Ashā'ir, said: "A large crowd of physicians has assembled, but Hāshim is not among them. By Allāh, O my Lord, none of them is his equal.” Ahmad said to her: "Have him come to me secretly, so that I may talk to him." She secretly brought him to Ahmad after encouraging him to speak. ${ }^{505}$

As the narrator tells it, the women in this case are happy to draw on the expertise of the male physician, even when it comes to feminine matters such as fertility.

There are many such accounts in Ibn Abī Ușaybī'a’s work, including mentions of private meetings between physician and female patient. ${ }^{506}$ Rarely are modesty measures mentioned in these circumstances. An interesting exception to this rule can be seen in Ibn Abī Ușaybía's anecdote about the $7^{\text {th }} / 13^{\text {th }}$-century court physician in Cairo, Rashīd al-Dīn Abū Ḥulayqa. Ibn Abī Ușaybī‘a recounts a story about Rashīd al-Din's skill. In the story, the physician engages in taking the pulses of all the sick women in the sultan's household, whom he cannot see because they are hidden behind a screen. The sultan himself decides to hide behind the screen together with the women and extends his own arm out in turn. The physician recognizes, by the precise measure of the pulse, that it is in fact that of the ruler, and not of anyone else. ${ }^{507}$ The story is interesting because, in mentioning the screen, it suggests that a physician might interact with and even touch a patient without being able to physically see her. However, such measures are not mentioned anywhere else in the biographical dictionary, despite many stories of interactions with female patients. It could well be that the screen is a mere literary device, meant to show off (as it clearly does) the physician's prowess, or else it represents a particular stringency unique to the female members of the royal household in that particular era. ${ }^{508}$

Other genres of literature, less focused on enhancing the reputations of individual physicians, also mention male physicians treating female patients and otherwise interacting with women of the household. A fascinating, if problemat-

505 Translation from Kopf, Lives of the Physicians, 688. Ibn Abī Ușaybi'a, 'Uyūn al-anbā' fì țabaqāt al-ațibbä', 543.

506 Ibn Abī Ușaybi‘a, 'Uyūn al-anbā' fī țabaqāt al-ațibbā', 637.

507 Ibn Abī Ușaybi‘a, 'Uyūn al-anbā' fì țabaqāt al-ațibbā', 592.

508 In her discussion of Ottoman medicine, Miri Shefer-Mossensohn explores how women of the highest rank had more limited access to medical care than those of less exalted social position, as a result of the demands of modesty. M. Shefer-Mossensohn, Ottoman Medicine: Healing and Medical Institutions, 1500-1700 (Albany: SUNY Press, 2009), 130-1. 
ic, source of medical practice is a treatise written by the Cairene jurist Ibn al-Hājj al-'Abdarī (d. 737/1336), in which he castigates his own community for what he believes are the many moral degradations of his age. (This treatise will be examined in more detail in the subsequent chapters.) Among the many reprehensible behaviors he condemns is his fellow Egyptian Muslims' choices when seeking medical care. He is particularly upset with Muslims who summon non-Muslim physicians instead of Muslim ones to tend to members of their household. In his treatise, he lays out many reasons why such conduct is unseemly, one of which focuses on women:

Even if nothing happens except that the infidel describes a Muslim's wife or daughter to someone else . . . it would be too much for Islamic protective jealousy (al-ghayra al-islāmiyya), even if it were not forbidden in the noble Law, ${ }^{509} \mathrm{God}$ forbid. If someone were to say: 'But the jurists have permitted uncovering nakedness before a physician whether the patient is a man or a woman!' the response is that this is the case only when there is a necessity, and there is no necessity that calls for inviting an infidel when there exists a Muslim physician. ${ }^{510}$

The central argument in this passage is an attack on medical interactions that cross the religious divide, not ones that cross the gender divide. However, the argument implies that both Ibn al-Hājj and his hypothetical interlocutor assume that a male physician is expected to see female patients. Moreover, from the interlocutor's statement "but the jurists have permitted uncovering nakedness before a physician whether the patient is a man or a woman," we can infer that this environment is one in which a significant portion of the population assumes that, in a medical context, female nudity is unproblematic. Indeed, the religiously zealous Ibn al-Hājj does not dispute this point, rather he argues that such mixed-gender interactions are only permitted if it is a matter of necessity, and there are no medical occasions which require an interaction that crosses the boundaries of both gender and faith. ${ }^{511}$ The former is admittedly necessary and acceptable; the latter, he argues, should not be.

509 I.e. Even if the reader were to deny his previous stated arguments showing that choosing non-Muslim physicians contravenes the sharia, a Muslim man should still disdain such behavior on the grounds of ghayra, appropriate sexual possessiveness.

510 Ibn al-Hāìj, al-Madkhal. 3/4:318.

511 There is a great deal of both primary sources and scholarly literature about interreligious medical mixing in the Mediterranean, from the late antique era through the end of the middle ages and beyond. It is not uncommon to find Jewish, Christian, and Islamic texts that condemn such mixing while at the same time confirming its prevalence. See chapter 6 . 
Evidence of the communication of medical knowledge across the gender divide can be found in a variety of texts that express concern that physicians or pharmacists (both are mentioned) may teach women which drugs are abortifacients, or may furnish women with the drugs. The concern is either that women may in turn use them on themselves or surreptitiously poison another woman out of spite. Some books, including hisba manuals, specifically tie this concern to the need to uphold the Hippocratic Oath. ${ }^{512}$ A detailed warning about such communications can be found in a medical ethics treatise by the $3^{\text {rd }} / 9^{\text {th }}$-century Baghdadi Christian physician Isḥāq b. 'Alī al-Ruhāwī:

If you are understanding, $\mathrm{O}$ friend, you have the advice of the great Hippocrates. He said that you must not mind the impatience of a woman whom you see distressed and afflicted due to her gestation, and not pity her or give her a remedy to make her fetus fall. Whoever does so has no fear of God. There is no reason to kill the fetus. On the contrary, it is necessary to raise it for this brings with it a worthy remuneration.

As to a bad mother, do not show any compassion for her, so that her shame will cause the improvement of many other women. Beware of giving things [i.e. abortifacients] like these; they are prescribed only if you fear the death of the pregnant woman or the fetus. There is no difference whether you administer the drug or you sell it. Before deciding on the drug treatment, it is essential that you read the book of Hippocrates in regard to his oaths to carry out his word. You must adhere to his oaths and go along with his beliefs from which the oaths are derived since these belong to the art of medicine. These must be observed under all conditions. ${ }^{513}$

... Together with being concerned about the sellers and storekeepers of the remedies which we have presented, the physician must warn the drug merchant not to give women drugs which make the fetus fall and menstruation flow without his permission. ${ }^{514}$

These exhortations against providing abortifacients indicate that physicians communicated directly with women about matters related to pregnancy. One could possibly read these texts about avoiding abortifacients as simply repeating traditional wisdom, rather than reflecting actual medical practice but, at least in al-Ruhāwī's case, the details suggest a substantial degree of immediacy. He cautions the physician that his "pity" and "compassion" when he sees a "distressed," "afflicted," and "shamed" pregnant woman should not move him to help her procure an abortion. This, in my view, suggests that al-Ruhāwī is speaking from experience, either his own or that of his fellow physicians.

512 Al-Shayzarī, 98. The Ma'ālim al-qurba fĩ aḥkām al-ḥisba, 167 in Arabic text. Also in Ibn Bassām, Nihāya al-rutba fĩ țalab al-hisba (Beirut: Dār al-Kutub al-'Ilmiyya, 2003), 340.

513 Translation in Martin Levey, "Medical Ethics," 56.

514 Ibid., 62. Levey's translation with some significant emendation. 
To be sure, depictions of charlatans, mountebanks, and disreputable physicians describe them as being on even more familiar terms with women than is proper. Thus Saladin's physician Ibn Jumay' complains that deceptive physicians reach clientele by "gaining the favor of their wives through suitable and alluring drugs, like aphrodisiacs, medicaments for conceiving, fattening and hair-growing by making common cause with the female bath-attendants, hairdressers and midwives, in order that they should talk about them and praise their wonderful medical skill." 515 Here the charge against charlatans is not so much immodesty as playing to the female crowd and consummate networking by means of cultivating relationships with women who are in para-medical professions. This brings us to the question: what sort of relationship did male physicians have with midwives, and did men play a gynecological role with or without midwives as intermediaries?

\section{Gynecological care and interactions between male physicians, female patients, and female intermediaries}

In spite of the above-mentioned references to interactions between male physicians and female patients, there is much evidence to suggest that, in the societies from which our texts derive, it was taboo for male physicians to view or touch women's genitals, or at least some women considered the matter in that light. We see this primarily in literary anecdotes. In Ibn Abī Ușaybī‘a’s biographical dictionary, the story is told of Jibrā'īl ibn Bukhtīshū' ibn Jūrjīs, who cures a woman of paralysis during an examination simply by bending his head down and extending his hand toward her skirt as though he intended to lift it, thereby awakening the woman's self-protective instincts. ${ }^{516}$ In al-Faraj ba'd al-shidda, alTanūkhì tells the story of a wealthy young woman in the countryside who attempts to conceal a terrible pain and discharge in her vagina. Her father, upon finally discovering that she is sick and on death's door, sends for medical care.

I sent for Yazīd the Urinanalyst and consulted him.

"Would you forgive me," Yazīd asked, "if I make a suggestion? I can issue no prescription unless I am allowed to see the site of the complaint and palpate it with my own hands, and ask the woman questions as to how the disorder may have arisen.” Her condition was

515 Ibn Jumay', al-Maqāla as-Ṣalāḥiya = Treatise to Șalāh ad-Dīn on the revival of the art of medicine by Ibn Jumay': edited and translated by Hartmut Fähndrich (Marburg: Kommissionsverlag F. Steiner, 1983).

516 Ibn Abī Ușaybi‘a, 'Uyūn al-anbā' fì țabaqāt al-ațibbā', 188. 
now so serious, indeed desperate, that I consented; but after he had examined her externally and found the site of the pain, his questions went on for so long and had so little to do with her illness that I felt tempted to lay violent hands on him. However, I reminded myself of the good character that he bore, and contained myself with difficulty.

The father's impatience with Yazìd, and his need to calm himself by reminding himself of Yazìd's good character, does not appear to stem from his concern that the man is touching his daughter, but rather that the man is asking her seemingly pointless questions instead of helping her.

At last he said:

'Have someone hold the girl down.'

I gave the order; he thrust his hand into her vagina; she screamed, then fainted; blood spurted out, and he withdrew his hand, displaying a creature smaller than a dung-beetle, which he tossed aside. The girl immediately sat up, crying: 'Papa! You must send this man out of my room, for I am well again. ${ }^{517}$

The story goes on to explain that the source of the trouble was a tick, contracted while tending cattle. Both stories, about the paralysis and the tick, suggest that modest female patients might be reluctant to have male physicians see or touch their genitals, but that doctors themselves do not have compunctions in this regard. Illness, where it is present, suspends the dictates of modesty. The restoration of such dictates, and deference to women's preferences, is the marker that the medical emergency is over, having been resolved through the cleverness of the physician.

A less celebratory and more mundane expression of women refusing to seek out treatment offered by male physicians can be seen in the famous Sevillian physician Ibn Zuhr's account of having in his youth once come across a woman with a prolapsed uterus, who had not sought male medical care for it. He laments:

Know that when I was a youth I saw a woman to whom this had happened, and her uterus was like a bracelet which was showing through her vagina. It had been that way for a long time. I do not know what happened to her. Had this been recent, the physician would have been able to undo the injury, God permitting." ${ }^{518}$

517 al-Tanūkhī, Faraj ba‘d al-shidda (Beirut: Dār Sādir, 1978), 4:215. Translation in Julia Bray, Writing and Representation in Medieval Islam (London: Routledge, 2006), 225.

518 Abū Marwān 'Abd al-Malik ibn Zuhr, Kitāb al-taysīr fĩ al-mudāwāh wa'l-tadbīr (Damascus: Dār al-Fikr, 1983), 308-309. 
The most explicit description of how sexual propriety factors into medical care appears at the beginning of a chapter in the Surgery of al-Zahrāwī, who practiced in Cordoba in the $4^{\text {th }} / 10^{\text {th }}$-century. The chapter describes an operation to remove bladder stones. The operation required a medical practitioner to insert his finger either into the anus (if the patient was a male or a virgin female), or into the vagina, to feel for the stone and, using both the inserted finger and an external hand to press down on the bladder, to manipulate the stone to a location near the groin. The practitioner would then make an incision to surgically cut the stone out. He writes:

It is uncommon for a woman to have a stone. But if it should happen to a woman the treatment is indeed difficult and hindered by a number of things. One is that the woman may be a virgin. Another is that you will not find a woman who will expose herself to a (male) doctor if she is chaste or has close male relatives (lā tujid imra'a tubìh nafsahā lil-țabīb idhā kānat 'afífa aw dhawāt al-mahărim). ${ }^{519} \mathrm{~A}$ third is that you will not find a woman competent in this art, particularly not in surgery. Then a fourth is that the place for cutting upon the stone in a woman is a long way from where the stone lies, so the incision has to be deep, which is dangerous. If necessity compels you to this kind of case, you should take with you a competent woman doctor (imra'a țabiba muhsina). As these are very uncommon, if you are without one then seek chaste/eunuch doctor as a colleague (fa-uṭlub țabỉban 'afifan rafiqan), ${ }^{520}$ or bring a midwife experienced in women's ailments or a woman to whom you may give some instruction in this art (imra'a tushīr fī hādhihi al-șinā'a ba'd alishāra). Have her with you and bid her do all that you enjoin; first of all, in searching for the stone. If she perceives that the woman is a virgin she should pass her finger into the anus and palpate for the stone. If she finds it and keeps her finger on it, then bid her cut down upon it. But if the patient be not a virgin bid the midwife pass her finger into the vulva and palpate for the stone, after she has placed her left hand upon the bladder and applied a good pressure. If she finds the stone she should gradually push it down from the outlet of the bladder as far as she can until it reaches the bottom of the pelvis. Then she should cut down upon it from about the middle of the pudenda near the root of the hip on whichever side she can conveniently feel it; she must keep her finger on the stone, pressing from below. The incision should start by being small; then let her introduce a sound into the small incision, and when she finds the stone then she will enlarge the incision until she knows that it is big enough for the exit of the stone.

519 Spink and Lewis translate "dhawāt al-mahārim" as "married" rather than "having close male relatives."

520 The Arabic word describing this doctor is " afif" i.e. "chaste," which is not the usual term for a eunuch, though 'Afïf seems to have been commonly used as a personal name given to eunuchs. However, given the context, I think Lewis and Spink's interpretation of ' $a$ fif $f$ as eunuch is plausible. 
... If you are hindered by a hemorrhage . . . after some days, when the acute hemorrhage has subsided and suppuration has set in, return to your operating until you get the stone out. ${ }^{521}$

From this description, which is the clearest one we have, it seems that al-Zahrāwī would ideally team up with specially trained eunuchs and women and direct them as they performed examinations and surgeries on women. It should be noted here that while most of the content of this chapter is taken verbatim from the Byzantine physician Aetius of Amida's encyclopedia, ${ }^{522}$ all of the passages about midwives, eunuchs, assistants, virgins and chastity seem to be original to al-Zahrāwī. ${ }^{523}$ This suggests that these original additions reflect al-Zahrāwì's own place and time. (I have been unable to find any other mention of eunuch physicians in medieval Arabic literary or documentary sources, however they are known to have attended nuns in Byzantium. ${ }^{524}$ ) Interestingly, he admits that there are few opportunities for a physician to practice this particular surgery. Such admissions are not present in most of his other descriptions of performing operations on women, which would imply that he views those other operations as practical, rather than rare-to-the-point-of-being-theoretical. He connects the rarity of bladder-stone removal surgery specifically to the sensibilities of respectable women, rather than to any reluctance on the part of the physician, or to external policing. Furthermore, his mention of the possibility of teaming up with women doctors as well as midwives and the physician's own female trainees, suggests that he views it as not impossible for a woman to receive some degree of instruction, such that she is conversant with the medical worldview of male practitioners of Arabo-Galenic medicine, even if such a woman is a rarity. By comparison, writing in the same century but on the other side of the Muslim world, Ibn Sīnā discusses the same operation, but makes no mention of a female practitioner or of particular modesty concerns, de-

521 al-Zahrāwī, Albucasis on Surgery and Instruments, M. S. Spink and G. L. Lewis (Berkeley: University of California Press, 1973), Book 30, Chapter 61, 420-423. The translation is a modified version of Spink and Lewis's.

522 Spink and Lewis note the correspondence between the two works, but not the discrepancies. Otherwise, they uncharacteristically choose to not comment on the chapter at all, on the grounds that it "needs no note." Ibid., 420.

523 Cf. Aetius of Amida, The Gynaecology and Obstetrics of the VI Century, chapter XCIX, 105. 524 Kathryn M. Ringrose, The Perfect Servant: Eunuchs and the Social Construction of Gender in Byzantium (Chicago: University of Chicago Press, 2003), 83. 
spite his detailed explanations and warnings about the operation and its permutations. ${ }^{525}$

Another description of the same procedure, from $7^{\text {th }} / 13^{\text {th }}$-century Syria, provides us with a similar account of women's reluctance to undergo bladder-stone removal surgery but seems to take it as a given that the surgery would have to be performed by a woman. The physician Ibn al-Quff writes:

\begin{abstract}
When stones occur in the bladder of women, their treatment is complicated by five factors: one of them is that the woman might be a virgin, and so there is no path for inserting the finger in the vagina so as to find the stone. Second: few women come forward to undergo said treatment, due to the pain of the incision. Third, we do not find a woman who will permit herself such surgical treatment because they are overcome by bashfulness. Fourth: because the location of the stone is further in them and requires a deeper incision, and that is dangerous. Fifth, she may be pregnant there is a concern that the incision will injure the fetus . . . But, if you want [or: she wants ${ }^{526}$ ] to attempt to remove it, then seek an expert, intelligent midwife, and order her to do everything that you say . . . ${ }^{527}$
\end{abstract}

He does not imply that such "expert, intelligent" midwives are rare, as alZahrāwī does, nor that it is acceptable for a man to engage in the surgery, as Ibn Sīnā does. We thus see a diversity of attitudes toward the proper division of labor between male and female practitioners with respect to this procedure. It is not clear why this procedure in particular should serve as the context for Ibn al-Quff's elaborations on women's "bashfulness" and al-Zahrāwì's elaborations on allaying modesty concerns. The most likely explanation seems to be that - since there was a long history of offering different methods for removing stones based upon whether the patient was a man, virgin woman, or non-virgin woman - it may have seemed particularly appropriate to build off of that discussion to tangentially address how patients' social identities affect their medical care.

We have remarkably few references to either the existence of or the training of the "competent woman doctor" whom al-Zahrāwī mentions as being so rare. Certainly, the feminine noun "tabiba" i.e. "doctoress" exists, but in the pre-Ottoman period it does not seem to refer to a woman trained in Arabo-Galenic med-

525 Ibn Sīnā, Qānūn fī al-țibb, 2:510 = kitāb III: fann 19: maqāla 1: faṣl fĩ al-tadbīr [re: hị̣̂āt almuthāna].

526 The verb used here is ambiguous and can be read as a second-person masculine or thirdperson feminine form.

527 Abū al-Faraj ibn Ya'qūb Ibn al-Quff, Kitāb al-'Umda fĩ al-jirāḥa (Hyderabad: Majlis Dā’irat al-Ma'ārif al-'Uthmāniyya, 1937) 2:210 -11. 
icine. ${ }^{528}$ More common are references to women ophthalmologists. The most expansive account of women receiving training from a physician in the Arabo-Galenic tradition can be found in Ibn Abī Ușaybi'a's description of the multiple generations of the Ibn Zuhr physician-dynasty that flourished in Spain. He writes that the sister and niece of al-Hafīd Abū Bakr ibn Zuhr (d. 596/1199) "were knowledgeable in the art of medicine and treatment, and they had much experience in matters pertaining to the treatment of women. And the two of them would attend the women of al-Manșūr and no one would deliver the children of al-Manșūr and his household except for al-Hafīd's sister Rufayda, or her daughter when her mother died." "529 Ibn Abī Ușaybi'a also claims that the caliph's vizier had both Ibn Zuhr and his niece assassinated, an indication that both occupied positions of power. We know little else about these female physicians, not even the name of the assassinated woman. It is reasonable to surmise that the phenomenon of female relatives of physicians practicing gynecological and obstetrical medicine themselves occurred with some frequency, but there are few extant references to such individuals. ${ }^{530}$ This is not to suggest that women who provided care were a rarity. There is little reason to doubt that women in general, as part of their role as mothers, wives, sisters, daughters, cooks, and producers and consumers of local knowledge of plants, stones, and magic provided much of the day-to-day care for sick people in both the Middle East and in Europe up until the modern period. ${ }^{531}$ However, there is no extant record of female medical providers studying medical books or being trained in the AraboGalenic medical tradition. ${ }^{532}$

528 S. D. Goitein writes that the word țabiba occurs several times in the documents of the Cairo Geniza, but he believes these refer to women from lower strata of society, not classically trained physicians. See Goitein, Mediterranean Society, I:127-8.

529 Translation from Kopf, Lives of the Physicians, 664. Ibn Abī Ușaybi‘a, 'Uyūn al-anbāa fì tabaqāt al-ațibbä', 524.

530 These few are identified in Giladi, Muslim Midwives, 70-71. The biographical details are quite scant. In the Ottoman period we hear of an unnamed daughter of the chief physician of the Manșūrī hospital in Cairo, who herself inherited his position after his death in 1036/1626. 531 Savage-Smith and Pormann, Medieval Islamic Medicine, 103.

532 Muhạmmad b. Ibrāhīm al-Jazarī’s (d. 738/1338) biographical dictionary includes a reference to a Cairene woman named Umm Khayr Khadīja bint al-imām Fakhr al-Dīn al-Nawzari (d. 733/ 1333) who both knew how to write and, in her old age, served as a midwife to the sultan's wife. However, her writing seems to be connected to her religious scholarship, not to any medical knowledge she might have. Apart from her serving as a midwife, there is no indication that she has access to any sort of medical scholarship. Al-Jazarī, Ta'rīkh hawādith al-zamān wa-anbā’ihi wa-wafayaāt al-akābir wa’l-a’yān min abnā’ihi (Beirut: al-Maktaba al-‘Așriyya, 1998) 3:701. 
Although the "competent woman doctor" is so rarely mentioned in medical literature, the figure of the midwife appears much more frequently, sometimes as a subordinate and informant, and sometimes more as a colleague. Descriptions of the extent of physicians' dependency upon midwives vary considerably in the medical literature. While there are many references to cooperation between midwives and physicians in the medical compendia, it is just as common for texts not to indicate the presence of an intermediary at all, even in gynecological situations. It should be noted here that it is often difficult to discern which tasks are performed by the male physician, which by female attendant(s) or midwives, and which by the patient herself. In part this is due to the frequent use of passive verb forms in these texts. The matter is further complicated by the fact that it is often grammatically unclear whether the active indicative verbs in Arabic medical manuals are intended to be read as second-person masculine forms or thirdperson feminine forms. ${ }^{533}$ Imperative verb forms, however, make the gender of the practitioner somewhat clearer.

Unsurprisingly, interactions between midwives and physicians frequently appear in discussions of childbirth complications. Once again, the most detailed description of such cooperation is found in al-Zahrāwì's text, in his chapter on handling difficult childbirth. The chapter seems to indicate that the male physician has visual access to the laboring woman. However, the physical interventions in the delivery are conducted by the midwife.

The midwife must have wisdom and dexterity and be skilled in all these cases and beware of failures and mistakes. I shall explain the technique in these modes of delivery so that she [or: you masculine] may be instructed and may be acquainted with them all.

When the fetus comes out by the vertex in the normal manner and yet the delivery is with great difficulty for the woman and you see that her strength is exhausted, then make her sit on a seat and order the women to take hold of her and foment her womb in a decoction of fenugreek in bland oils. Then the midwife should take between two fingers a little scalpel and make an incision in the fetal membrane or open it with the finger nail, to allow the contained waters to flow out; and put pressure upon the woman's abdomen until the fetus comes down ....534

As the chapter continues, however, in addition to using gender-ambiguous verbs al-Zahrāwī also begins using masculine imperatives for actions that require intimate contact with the woman in labor, such as "place $\left[d a^{6}=\right.$ masculine imper-

533 Weisser makes this same point, see Zeugung, Vererbung, und pränatale Entwicklung, 56-59. 534 al-Zahrāwī, Albucasis on Surgery and Instruments, 468-471. The translation is that of Spink with some additions to show grammar. More substantial emendation occurs in the second paragraph. 
ative] the woman upon a platform . . . and shake [masculine imperative] the platform." If the baby emerges feet first, he writes "return [masculine imperative] the fetus bit by bit [into the uterus] until you have placed it in a natural position." He suggests that, if all else fails, the physician should make a compound and "anoint [masculine imperative] with it the vagina of the woman and her lower abdomen" and later "press [masculine imperative] gently upon her abdomen."535 The chapter thus leaves the reader with an image of both male and female practitioners engaged in gynecological practice, at least during medical emergencies. ${ }^{536}$

In another, remarkable depiction of cooperation during an emergency obstetrical operation, al-Zahrāwī explains how to make and use a speculum for opening the womb to extract a stillborn fetus. ${ }^{537}$ He then writes:

When you wish to open the womb with this [speculum], make the woman sit on a couch with her legs hanging down, parted; then introduce the two projections [of the speculum] into the orifice of the womb while you hold [masculine] the end of the instrument lower down between her thighs; then open your hand in the same way as you would with forceps, to the extent to which you wish to open the womb, so as to allow the midwife to see what she desires. ${ }^{538}$

Interestingly, this depiction of the interaction between the physician and midwife does not make clear the hierarchy of roles. One could well read this as the male medical practitioner supporting the more expert midwife.

The division of labor and extent of cooperation between midwives and male physicians is more ambiguous in Ibn Sīnā's Qānūn. Ibn Sīnā mentions the role of midwives as informants quite often, both in emergency and in non-emergency situations. For example, he mentions soliciting information from a midwife in the case of an abnormally positioned uterus.

535 Ibid., 471.

536 This can also be seen in Hippocratic and other Greek texts. As Leslie Dean-Jones notes, "there is a division of labor within a single case." Dean-Jones, "Autopsia, Historia, and What Women Know: The Authority of Women in Hippocratic Gynecology," in Knowledge and the Scholarly Medical Traditions, ed. Donald George Bates (Cambridge: Cambridge University Press, 1995), 55.

537 For a fascinating discussion of how fetal-extraction procedures in medieval Arabic texts were understood and reinterpreted by early-modern European physicians in light of their own innovations in forceps-assisted delivery see H. King, Midwifery, Obstetrics and the Rise of Gynaecology: The Uses of a Sixteenth-Century Compendium (London: Routledge, 2017), 142.

538 al-Zahrāwī, Albucasis on Surgery and Instruments, 486-9. Spink's translation with my clarifications in brackets. 
Chapter on the declination and distortion of the womb: it is possible for the uterus to incline towards one of the woman's sides, such that the mouth of the uterus is no longer aligned with the path through which the semen flows to it ... The midwives know the direction of the inclination by feeling with their fingers, and they will know whether it is due to rigidity or laxness . . .539

Even as he describes midwives taking the role of genital touching, Ibn Sīnā claims that he is directly involved in patient care, and that he is giving instructions to the midwife and patient.

In other places, Ibn Sīnā gives the impression that the male physician personally oversees and administers gynecological treatment without the mediation of another woman. For example, as part of his description of a method for extracting the placenta after birth, when it has not already emerged, he instructs the physician: "Use substances to induce sneezing . . . once the mouth of the womb dilates, then you insert your hand and extract" the placenta. ${ }^{540}$ The instructions in this sentence are grammatically unambiguous, addressing a male in the second person, and directing him to introduce his hand into the birthing woman's uterus.

Ibn Sīnā similarly depicts the male physician as directly involved in the delivery process in his description of abortion procedures and the extraction of a stillborn baby after an arduous labor.

\begin{abstract}
The management of miscarriage and expelling the dead fetus: At certain times, abortion may be necessary, among them: when the pregnant woman is a small girl whom one fears will die from childbirth. Also when there is a lesion within the womb and extra flesh which makes the exit too small for the baby and it is killed. Also when the fetus has died within the womb of the pregnant woman. Know that if the woman has experienced four days of difficult labor, then the fetus is already dead, so busy yourself [masculine] with the life the mother, and do not busy yourself with the life of the fetus, rather strive [masculine] to expel it. [This] abortion is brought about by means of movements or by means of drugs. The drugs can do so either by killing the fetus, or by forcefully bringing down menstruation..${ }^{541}$
\end{abstract}

From this description, it seems as though Ibn Sīnā expects the physician to be personally ministering to the laboring woman and extracting the deceased baby himself. There is no mention of a midwife throughout this passage.

539 See Ibn Sīnā, Qānūn fī al-țibb, 2:596= kitāb III: fann 21: maqāla 4: faṣl fī mīlān al-rahīm. 540 Ibn Sīnā, Qānūn fī al-țibb, 2:580 = kitāb III: fann 21: maqāla 2: fī ikhrāj al-mashīma 541 Ibn Sīnā, Qānūn fī al-țibb, 2:578 = kitāb III: fann 21: maqāla 2: tadbīr al-isqāṭ wa-ikhrāj aljanin al-mayit. 
Compare Ibn Sīnā's discussion of a difficult labor above with another surgical passage about expelling a dead fetus, for which he assigns a much larger role to intermediaries. He describes the midwife as engaged in the grizzly business of drawing out the fetus by means of hooks poked into its body. He attributes this technique to "the ancients," thereby implying that such a procedure was in his own time a theoretical one, rather than one commonly practiced.

\begin{abstract}
The [pregnant] woman must lay on the bed on her back, with her head tilted downward and her thighs raised. Then women, or a servant, grasp her on either side. If these [people] are not present, then tie [masculine] her chest to the bed with knots so that her body will not be pulled down when it is stretched. Then the midwife opens that which is covering the neck of the uterus, anoints her left hand with oil, brings her fingers together lengthwise, and inserts them into the mouth of the uterus and dilates it with them. More oil is added, and she ascertains whether it is necessary to insert hooks with which the fetus may be drawn out, and the places which are best for inserting the hooks. These places, in a fetus which is presenting head-first, are the eyes, the mouth, the nape $\ldots{ }^{542}$
\end{abstract}

He goes on to describe the piercing process, and then how to modify that process when the fetus presents feet first, an operation which involves not one hook but two. What is odd about the descriptions of these two procedures for dealing with abortion and obstructed labor is that the first one, featuring a male physician giving his patient expulsive drugs, is quite feasible in terms of medieval medical technique, but the presence of a male medical practitioner does not conform to our expectations of medieval births. By contrast, the second procedure features a female medical practitioner practicing obstetrics, which seems more true-to-life, but it also describes a surgical technique which most likely was never implemented. ${ }^{543}$ This discrepancy suggests that we should not view the presence of a midwife in a medical text as correlated with the sensitivity of a particular medical problem or as correlated with the feasibility of a particular form of treatment.

Midwives are also depicted as working in conjunction with male physicians in non-emergency situations which require inserting fingers into the patient's body. Ibn al-Jazzār, writing in $4^{\text {th }} / 10^{\text {th }}$-century Qayrawān, deals extensively with gynecology, explaining diagnostic measures and offering a variety of pessaries, pills, and fumigation techniques for treating women's genitals. In those chapters, he mentions the presence of a midwife only twice, once in connection with the treatment of hysterical suffocation, and the other time when discussing the diag-

542 Ibn Sīnā, Qānūn fī al-țibb, 2:576 = kitāb III: fann 21: maqāla 2: faṣl fĩ tadbīr li-ba’̣̣ alqudamā' fī ikhrāj al-janīn al-mayit.

543 Savage-Smith, "The Practice of Surgery in Islamic Lands," 315. 
nosis of uterine tumors. In both cases he indicates that he is "instructing" the midwife.

We should tell the midwife to rub gently the orifice of the uterus from the inside and outside with one of the oils we have mentioned..$^{544}$

To diagnose the presence of a tumor, he writes:

If the tumor occurs in the front part of the uterus, it is followed by a heavy pain in the vagina with retention of urine, and if it occurs in the orifice of the uterus, it is followed by pain in the navel and stomach, and if the midwife inserts her finger, she finds the orifice of the uterus closed and hard. ${ }^{545}$

Elsewhere in the same text, Ibn al-Jazzār describes treating a prolapsed uterus with poultices, but he does not mention a midwife. However, the verbs are ambiguous, and can be read as either referring to a male physician binding the groin in a poultice or as a poultice being bound around the site of the injury, with the gender of the practitioner unstated. ${ }^{546}$

In al-Majūsī's al-Kāmil al-șinā'a fì al-țibb, 110 chapters of which are devoted to surgery, he explicitly states that it is the midwife who performs surgeries to treat rutqa (the condition mentioned in the previous chapter in which the vagina is too narrow or obstructed). She is also the practitioner who excises obstructions in the uterus arising from previous ulceration. ${ }^{547}$

Sometimes different works by the same author offer conflicting understandings of standard practice. This can be seen in al-Rāzì's works. Some of them contain references to dependence on midwives as intermediaries, while other books covering the same material have no such references. The following gynecological passages in al-Rāzì's $H+a \bar{a} w \bar{l}$, for example, imply direct contact between male physicians and female patients. The verbs directed at the physician here are all masculine singular imperatives.

The placenta: if you want to expel the placenta, dose her with a sternutatory drug then hold [sing. masc. imperative] her nostrils and mouth, for in such a situation the belly will stretch and tighten, which facilitates the expulsion [of the placenta]. ${ }^{548}$

544 Ibn al-Jazzār, Ibn al-Jazzār on Sexual Diseases and Their Treatment, 275.

545 Ibid., 277.

546 Ibid., 179.

547 al-Majūsī, al-Kāmil, 488.

548 For more on the role of sneezing in expelling the fetus see Batten, "The Arabic Commentaries On The Hippocratic Aphorisms,” 140-178. 
On fibroids: He said: Place [masculine imperative] a mirror under the woman so that you may see the thing as it really is. If there is intense pain present, have [masculine imperative] her sit on a laxative concoction ... ${ }^{549}$

To treat rutqa, whether it is congenital or as a result of a healed-over wound: Open [masculine imperative] the vagina of the woman and you shall find that the opening of the vagina is covered by something resembling a muscle. This is if the flesh is in the vagina. (If it is in the cervix, then there is nothing to worry about until the girl reaches [the onset of] menstruation, but then [menstruation] might be retained and not flow, and she will as a result experience intense pain and quickly die if she is not treated; and this is because all the blood returns to her body and rots and suffocates it) . . . but this flesh, when it grows in the opening of the vagina, makes it impossible for a man to have intercourse with her, and she cannot menstruate either and she cannot conceive. If it is in the cervix then she can have intercourse but she will not conceive. It may be that this flesh entirely blocks the [entrance to womb] and it may be that there is a small opening from which menses may exit, and it may be that such a [patient] does conceive but both she and the fetus die when there is no way for it to come out.

Other passages describe the physician relaying to the midwife that he needs certain information:

If you see retention of the menses ... tell the midwife to touch the cervix and if it is closed without being rigid it is a sign of pregnancy. ${ }^{550}$

The signs of pregnancy: the closing up of the mouth of the uterus. The mouth of the uterus closes when it is occupied and when there are tumors in it. The difference between them is that the tumor is accompanied by stiffness while the closing [of the uterus] due to its being occupied is not accompanied by stiffness, but rather it is in a natural state. The midwife should insert her finger to ascertain it. This is one of greatest signs from the uterus when it is shut. ${ }^{51}$

The Hiāwi consists of a great number of quotations from other writers which have not been edited and synthesized, and so it is entirely possible that none of the above passages reflects common practice in al-Rāzì’s own society.

Other works by al-Rāzī more clearly reflect a unified authorial voice, and we might turn to these to learn about the gendered division of labor in gynecological care. In al-Rāzī's Man lā yahduruhu al-țabīb he does not mention midwives at all. As for al-Rāzì's Manșūrī fì al-țibb, the modern editor of the only twentieth-century printed edition writes in a footnote that he has chosen to emend the text to limit cross-gender interaction:

549 Al-Rāzī, al-Hāāwì, 15.

550 Al-Rāzī, al-Ḥāwī, 9:49. Cf. Al-Baladī, Tadbīr al-ḥabālā’, 33.

551 Ibid. 51. 


\begin{abstract}
[glossing the phrase "he gives to the (female) patient"] "It is so in all versions. ${ }^{552}$ In these chapters which address women and those diseases of the menses and of the uterus which befall them, the author writes as though speaking about a male [practitioner]. Hence "he gives to the patient," "he administers," "he inserts," "he feeds," etc. We have tried to correct all of the words without pointing out every mistake in the footnotes. ${ }^{53}$
\end{abstract}

In other words, the modern editor chose to emend the text by changing the active masculine verbs, originally attributed to male physicians, to passive or feminine forms, some of which imply that the patient performs these actions on her own, and others implying the presence of a second woman acting as a medical intermediary. In this footnote, the editor notes that because there were so many such "problematic" references to the male practitioner, he felt it too cumbersome to draw attention to them all. The editor clearly doubts that the medical care mentioned by al-Rāzī could have been provided by a man.

The omissions of references to female intermediaries and practitioners where we might expect to find them has been catalogued by Avner Giladi, in his book, Muslim Midwives. He notes that "the midwife is altogether - or almost totally - ignored" in the major works by Thābit b. Qurra, al-Ṭabarī, al-Majūsī, Ibn Zuhr, and Ibn al-Nafīs. ${ }^{554}$ In omitting them, the authors instead appear to be addressing, at least grammatically, male practitioners.

Regardless of whether authors of medicals works include references to midwives or not, they all depict a landscape in which male physicians interact with female patients, including those with gynecological problems. They expect male physicians to be in a position to communicate with their female patients about drugs and sell them directly to them. They indicate that male physicians are present in the same room as their female patients and clients, able to speak to them, to look at and touch their patients' bodies to the extent that they could feel the pulse, assess the visual appearance of the patient, hold the patient's nose and mouth, and set up fumigations.

The respectability of genital touching is less clear. There are several references to the notion that women were reluctant to have male physicians see or touch their genitals. However, all of the references to this reluctance suggest that it stems from patient preference rather than medical ethics. Al-Zahrāwī and Ibn Sīnā refer to male involvement during emergency obstetric situations, involvement which appears to include manipulating the emerging baby, while other passages from the same works assign those tasks to the midwife.

552 I.e. All manuscripts use a masculine verb.

553 al-Rāzī, al-Manșūrī fĩ al-țibb, 448. .

554 Giladi, Muslim Midwives, 73-4. 
Both theoretical medical compendia and hisba manuals corroborate one another in providing the impression that male medical professionals sometimes provide clitorectomies, and male phlebotomists bleed women, and yet we do not see a code of professional ethics attached to those practices. These texts provide no guidance about how to touch patients while avoiding accusations of impropriety. One could well take this data point to mean that such touching rarely happened in actual daily experience. (It could, perhaps, be argued that such tasks are considered menial ones in some societies, and so are unlikely to be performed by men with extensive medical educations and less likely to receive the attention of ethicists.) If we were to argue, however, that these services were rarely offered by men of any class, and that in reality these services were segregated by gender, then we would be forced to argue against the extant textual record. In other words, while we do not have all the textual evidence we would expect from a society in which male practitioners frequently treat female patients in ways that involve touching, nonetheless we have too much evidence to be ignored that such interactions were common, and we have very little evidence to the contrary.

As for the extent to which midwives served as intermediaries, multiple sources depict physicians in non-emergency situations asking midwives to conduct examinations and relay information to them about how the cervix feels. The implication is that midwives are working in the capacity of assistants and informants to the physician. Whether it was standard procedure in any particular community for male physicians to have formal professional relationships with midwives is difficult to say. Hisba manuals and medical ethics treatises do not mention them. However, the reference to charlatans cultivating relationships with midwives suggests that perhaps midwives referred their patients to physicians or otherwise engaged male physicians as consultants. Moreover, one could argue that, just as midwives were known to serve as medical informants for the court system, they could have just as easily served as informants for physicians. From this evidence, it appears that at least some male physicians were working in close enough proximity with midwives and female patients to be able to share medical knowledge.

\section{Theory, practice, and women's access to Arabo-Galenic medical knowledge}

The portions of Arabo-Galenic texts pertaining to the treatment of women frequently provide detailed instructions to male physicians and are written as though such men are directly and physically involved in gynecological and ob- 
stetrical care. Does this mean that many medieval women likely were taught the Arabo-Galenic system for understanding infertility and participated in that understanding, or was their intellectual experience likely uninformed by such theories? There are three possible interpretations of the practical significance of Arabo-Galenic gynecological writings. (1) The purpose of the texts is to pass along entirely theoretical medical knowledge to physicians. The authors are not concerned about the practice and implementation of these instructions, rather this information exists only because of the medieval propensity toward theoretical thoroughness in encyclopedias. (2) These texts' instructions were intended to have practical value and to be implemented by female medical practitioners. The authors believed their instructions would be read by or otherwise orally conveyed to women who would implement them in gender-segregated settings. Where masculine language is used to describe practitioners, it is merely a grammatical or literary convention and is irrelevant to the meaning of the text. Or (3) the texts' instructions have practical value and were intended to be implemented by male physicians with the help of female assistants or informants. Each of these explanations is plausible but problematic. ${ }^{555}$

One could indeed make the argument that the instructions in these texts were never intended to be applied to the care of patients, and so Arabo-Galenic medical writings can tell us nothing about the kind of medical advice and treatment infertile women received. If so, this would not be unique to infertile women; much of medieval medical writing is thought to bear little relation to the practice of medicine. This seems to be particularly true of surgical medicine. ${ }^{556}$ Cesarean sections (including post-mortem ones) are the classic example of a procedure which is repeatedly discussed in medieval Arabic literature but which is not believed to have actually been attempted. The descriptions are too inaccurate and vague and the illustrations reflect hagiographic literary topoi - they are not medical diagrams. Emilie Savage-Smith quotes the $8^{\text {th }} /$ $14^{\text {th }}$-century Egyptian oculist al-Shādhilī in support of this argument.

We possess written accounts of various procedures which cannot be performed nowadays because there is no one who has actually seen them performed; an example is the instrument designed to cut up a dead fetus in the womb in order to save the mother's life. There are many such procedures: they are described in books, but in our own time [i.e. the four-

555 For an exploration of these issues in the medieval European context see, M. Green, Making Women's Medicine Masculine: the Rise of Male Authority in Pre-Modern Gynaecology (Oxford: Oxford University Press, 2008).

556 Savage-Smith, "The Practice of Surgery in Islamic Lands,” 307-321. 
teenth century] we have never seen anyone perform them because the practical knowledge has been lost, and nothing remains but the written accounts..$^{557}$

Al-Shādhilī appears to be referring to the procedures Ibn Sīnā mentioned, which called for physician-midwife cooperation.

Other surgical and cauterization procedures for removing bladder stones and tumors and treating hemorrhoids were indeed implemented, according to Savage-Smith. This conclusion is based on the fact that the instruments and instructions provided in the medieval literature were both technically possible to implement and were likely effective. Both medical texts and hisba manuals suggest that, at least in some places and periods, such surgeries were performed on women as well as men. This is not to say that no women would have compunctions about undergoing such procedures, but rather that such a degree of interaction between the genders was not unthinkable.

Descriptions of medieval Arabic non-surgical treatments of gynecological problems, and particularly of infertility due to amenorrhea, are dynamic, extensive, and detailed. There are literally dozens of recipes for oral pills, pessaries, and incense intended to draw down the menses and restart the reproductive cycle. This is also true of treatments intended to restore humoral balance to the uterus. Occasionally, the author will conclude a recipe with the claim that he has tested it and can confirm its effectiveness. Some of these recipes which appear in medical compendia also appear in pharmacy books such as the Minhāj al-dukkān. Taken together, such evidence indicates that authors did not view this part of their texts as unrelated to the practice of medicine.

A few trace references within these recipes indicate that the author thinks women might have access not only to male physicians, but to his text itself. These references all occur in recipes for contraceptives and abortifacients. Ibn al-Jazzār writes: "When I was reading the works of the ancient [physicians] who speak about the forces and helpful and harmful effects of the simple drugs, I found that they mention drugs which corrupt the sperm in the uterus and prevent conception, and drugs which kill the fetus and expel it from the womb. I therefore decided to mention the case of these drugs in this chapter,

557 Ibid., 315. Cf. Chapter 66 of al-Zahrāwī's surgery, in which he describes how to operate on "flatulent hernia," also known as pneumatocele. He writes, "I have not seen anyone pluck up enough courage to attempt the operative treatment of this kind of rupture, though the ancients said it ought to be done in the same way as hernia with varicocele, namely . . ." al-Zahrāwī, Albucasis on Surgery and Instruments, 447. 
so that they will be known and so that women would beware of using them." 558 In his Kāmil al-șinā'a al-țibbiyya, al-Majūsī writes:

As to medicines which prevent conception, although they should not be mentioned to pre-
vent their use by women in whom there is no good, it is necessary sometimes to prescribe
them to those women who have a small uterus, or those who have a disease which, in the
case of pregnancy, may cause the woman death in childbirth. Except for women in such pre-
dicaments, the physicians should not prescribe [these] medicines. Also, he should not pre-
scribe medicines which cause the menses to flow, or medicines which expel the dead
fetus, except to women he can trust, because all these medicines kill the fetus and expel it..$^{59}$

Ibn al-Jazzār's statement implies that what he writes eventually reaches women. Al-Majūsī's statement is somewhat more ambiguous. His phrase "they should not be mentioned" could mean that although it is safe to write about abortifacients for a (male) readership, the drugs should not be spoken of lest it reach the ears of women. Nevertheless, the participation of at least some women in the authors' community of knowledge is assumed.

As to whether women shared the physicians' understanding of humoral medicine - and their beliefs about the role of heat, cold, moisture, and dryness it seems that that was in and of itself a matter of debate, at least in some locations. Ibn Abī 'Ușaybī‘a writes:

I have it on the authority of the sage Rashīd al-Dīn Abū Sa'īd ibn Ya'qūb the Christian that Abū al-Hasan Sa'īd ibn Hibat Allāh was in charge of treating the sick at the hospital. One day, when in the lunatic ward in order to inspect and treat the inmates, a woman approached him and asked his advice concerning the treatment of her son. When he replied: "You should urge him to take cooling and moistening foods," one of the inmates of the lunatic ward mocked him, saying: "You had better give that prescription to one of your pupils, who has had some experience of medicine and knows some of its rules. As to this woman, what does she know about cooling and moistening things? You should have recommended her something specific that she might readily use." 560

This story, which is set in $5^{\text {th }} / 10^{\text {th }}$-century Baghdad, highlights the opinion that women could not participate in medical discourse in even the most basic way. Women could not even be expected to know what constitutes a "cooling" or “moistening” food. From the inmate's point of view, women might accept particular prescriptions offered by physicians, but they have no notion of how such

558 Translation from G. Bos in Ibn al-Jazzār, Ibn al-Jazzār on Sexual Diseases, 290.

559 Translation from B. Musallam, Sex and Society in Islam, 70.

560 Translation from Kopf, Lives of the Physicians, 480. Ibn Abī Ușaybi‘a, 'Uyūn al-anbā' fĩ țabaqūt al-ațibbā', 342-3. 
prescriptions are arrived at. Al-Ruhāwī too, writing in the previous century, claims that among the common people there is disagreement even about the axioms upon which all Galenic fertility medicine is based. He complains "There is also a widespread stupidity among the people that in certain illnesses they may be their own physicians. They believe . . . that women are hotter than men ..." ${ }^{561}$

Such statements indicate that there were alternative systems available to women for understanding physiology. Indeed, there is a great deal of medical writing in which male physicians complain that they do not command the respect from patients which they deserve, that the masses are ignorant of what decent medicine looks like, and that they are taken in by pseudo-doctors who do not understand basic science. Chapter 6 will explore this topic further. However, it would be a mistake to conclude that either the gender divide or the existence of popular alternatives to the Galenic medical system precluded the gynecological portions of Arabo-Galenic texts from having an audience or an impact on women's medical care.

561 Translation in Martin Levey, "Medical Ethics," 97. 